\title{
The dynamics of macrophytes in a lake in an agricultural landscape
}

\author{
Joanna Sender \\ Department of Landscape Ecology and Nature Conservation, University of Life Science in Lublin, Dobrzańskiego 37, 20-262 Lublin, \\ Poland; e-mail: joanna.sender@up.lublin.pl
}

\begin{abstract}
Macrophytes are a group of aquatic organisms affected by constant changes. One of the main factors influencing the rate and direction of these changes is the way of basin management. The aim of this study was to determine the effect of changes in the management of a lake catchment area in an agricultural landscape on the qualitative and quantitative structure of macrophytes and assessment of the ecological status of the lake in question. The study was conducted in the years 1996, 1999 and 2011 in Lake Głębokie Uścimowskie. This lake is small (20.8 ha surface) and shallow (about $6 \mathrm{~m}$ depth). In the 1990s in Lake Głębokie Uścimowskie from 14 to 15 plant communities occurred, which occupied 2.9 ha of the lake. This represented only $14.1 \%$ of the lake. In 2011 there was a slight growth in the number of phytocenoses (16), and significant increase in the area of phytolittoral - 5.98 ha. In the 1990s the range of ESMI index values, allowed the lake to be categorized as one with poor ecological status, but already in 2011 after a similar analysis, the lake was ranked in the upper limits of moderate ecological status of lakes. One of the main reasons for the rise in the ecological status of Lake Głębokie Uścimowskie, determined on the basis of the macrophyte index, as well as for the slight decline in trophy, was probably a sewerage system built in 2006 in Głębokie village.
\end{abstract}

Key words: macrophytes, shallow lake, ecological state, catchment, eutrophy

\section{Introduction}

Aquatic ecosystems are living organisms whose existence depends on the way of catchment area use. Macrophytes are one of elements creating an organism. The functional importance of aquatic macrophytes for biocoenoses goes beyond their trophic role. They provide a substrate for periphyton, as well as spawning fish and amphibians. They are also competitors of planktonic and peryphyton organisms for light. They limit movement of water in the littoral zone, and reduce the exchange of matter between the littoral and pelagic zone (Lampert and Sommer 1996). Macrophytes are good indicators of eutrophication. The main symptom of eutrophication is deteriorating light conditions, which are manifested by the disappearance of submerged macrophytes. The massive growth especially of helophytes and floating leaved vegetation is less favourable. Their massive growth causes shading, hampers the exchange of matter, limits the development of fauna, cuts off access to the bottom for invertebrate animals and fish, while preventing them mov- ing and feeding. Changes in the quality and quantity structure are significantly slower (Bernatowicz 1959).

Macrophytes are a group of aquatic organisms affected by relatively slow changes. However, their development can be substantially reduced, and the qualitative structure rebuilt under the influence of a surrounding lake catchment. Usage and management of the catchment area can significantly modify the structure of aquatic vegetation. Most often macrophytes reduce the extent of occurrence of biomass as well as species composition and spatial arrangement (Stefan 1997; Sender 2009). The degree of catchment area influence on the lake depends on the vegetation cover and composition of the shore, affecting the amount of surface runoff (Klosowski and Tomaszewicz 1996). Climatic, physiographical and geological conditions also have a large impact (HilbrichtIlkowska and Kostrzewska-Szlakowska 1999).

The aim of this study was to determine the effect of changes in the management of a lake catchment area in an agricultural landscape on the qualitative and quantitative structure of macrophytes and assessment of the ecological status of the lake. 


\section{Study area and methods}

The field study was conducted in three seasons (spring, summer, autumn) in the years 1996, 1999 and 2011 in Lake Głębokie Uścimowskie (N 51 ${ }^{\circ} 28^{\prime}$, E $\left.22^{\circ} 55^{\prime}\right)$. This lake is small (20.8 ha surface) and shallow (about $6 \mathrm{~m}$ depth). In the 1960s it was classified as a eutrophic lake (Fijałkowski 1960; Radwan et al.
1987), whereas since the 1990s as a hypertrophic lake (Radwan et al. 1998). This lake has a small catchment area covering 173.8 ha, typically agricultural land. From the north and west it is surrounded by Głębokie village and from the south and east by farmland.

The catchment area of Lake Głębokie Uścimowskie is agricultural. Fields surrounding the reservoir almost directly adjoin the shoreline (Fig. 1)

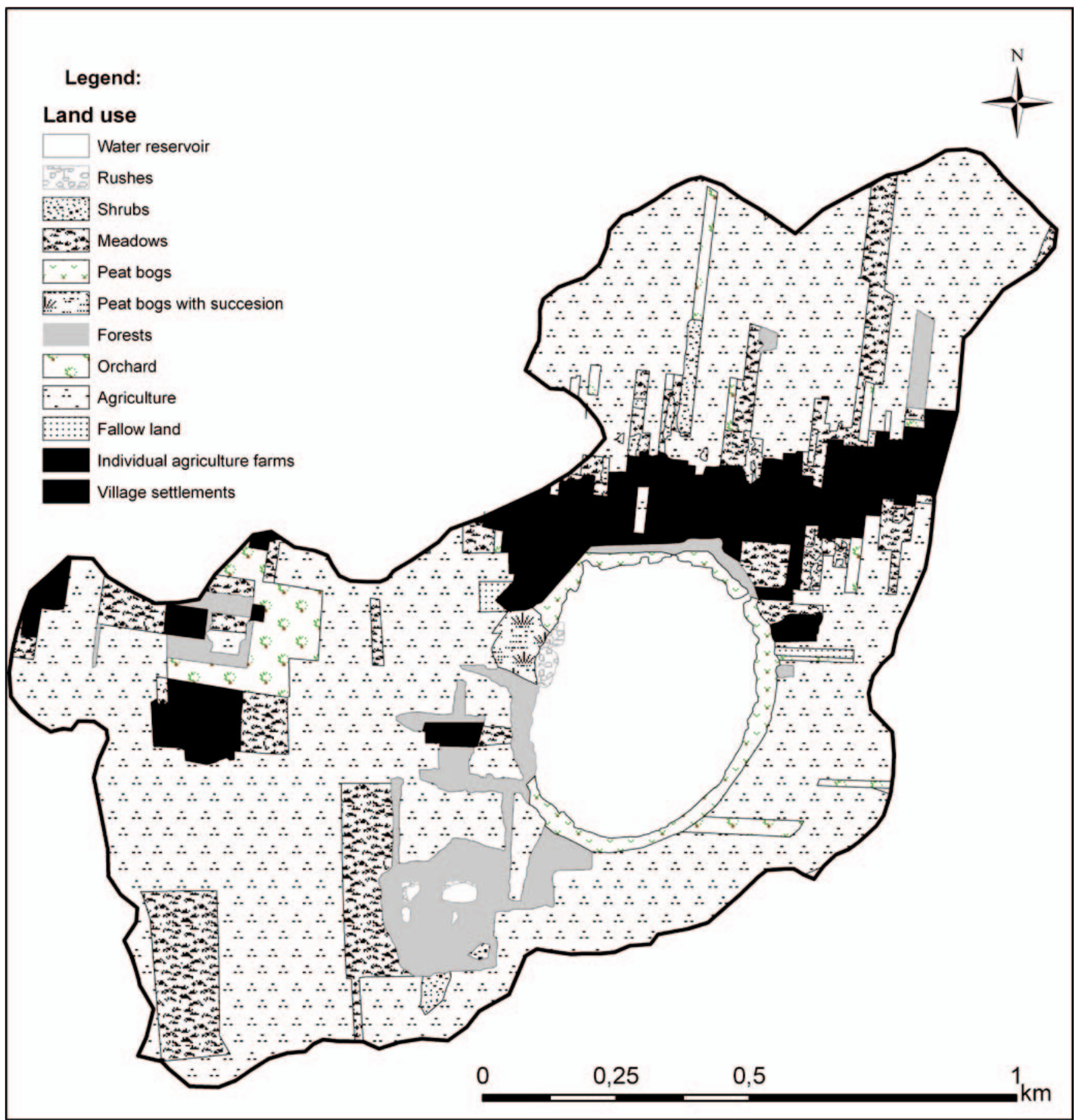

Fig. 1. Land use in Lake Głębokie Uścimowskie catchment area in 2009 
Management in the catchment area of the investigated lake has changed considerably over more than 10 years. First of all, there was a significant increase in the share of forests, as well as peat bogs. A larger share of peat bogs is the result of successional processes of stagnant water. There was also a clear increase in builtup areas (Table 1).

Plant communities were examined and identified based on the method of Braun-Blanquet phytosociological relevés (Fukarek 1967). The syntaxonomic system was adopted by Matuszkiewicz (2008).

Biomass, density, species composition and coverage of macrophytes were analysed in horizontal transects from the shoreline to the maximum range of their occurrence. Number and distribution of transects depended on differentiation and the way of management in the catchment area. Samples were taken at intervals of $0.5 \mathrm{~m}$ depth; for this purpose a floristic rake was used, whose surface grip was $0.16 \mathrm{~m}^{2}$ (Sender 2004). The surface phytolittoral and individual communities and the length of shoreline inhabited by macrophytes were determined on the basis of a current vegetation map of the lake using Macrostation ver. 8th programme.

In order to determine the ecological status of the lake the ESMI index was used (Ciecierska 2004, 2008).

Physical and chemical parameters of the water, such as visibility, water reaction $(\mathrm{pH})$, temperature, electrolytic conductivity, oxygen content, total $\mathrm{P}$, total $\mathrm{N}, \mathrm{N}-\mathrm{NH}_{4}, \mathrm{~N}-\mathrm{NO}_{3}, \mathrm{PO}_{4}, \mathrm{~K}, \mathrm{Ca}$, and $\mathrm{Na}$ were analysed. The following instruments were used for determination of physical and chemical properties of water: OXI 330 oxymeter made by WTW (oxygen content, temperature), electronic conductivity meter made by Hanna (electrolytic conductivity), and a microchip Slandi SP300 pH-meter (water reaction). The content of biogenic nitrogen and phosphorus compounds was determined using the microchip Slandi photometer LF 205.

Carlson's Trophic State Index (TSI) was calculated, based on visibility of a Secchi disk (SD), nitrogen (TN) and phosphorus (TP) content (Carlson 1977).

Table 1. Land use and its changes in the catchment area of Lake Głębokie Uścimowskie (acc. to Harasimiuk et al. 1998)

\begin{tabular}{|c|c|c|c|c|}
\hline Usage & 1998 & 2009 & $\begin{array}{l}\text { Difference in surface } \\
\text { [ha] }\end{array}$ & $\begin{array}{l}\text { Percentage change } \\
\text { in the surface [\%] }\end{array}$ \\
\hline Forests & 0.99 & 10.70 & -9.70 & -90.10 \\
\hline Meadows & 8.12 & 17.30 & -9.10 & -53.10 \\
\hline Fields & 127.73 & 98.20 & 29.50 & 30.00 \\
\hline Peat bogs & no data & 3.50 & 3.50 & 100.00 \\
\hline Peat bogs with succession & no data & 0.99 & 0.99 & 100.00 \\
\hline Water bodies & 20.86 & 17.60 & 3.30 & 18.50 \\
\hline Scrub communities & 0.67 & 1.90 & -1.30 & -65.00 \\
\hline Rushes & no data & 0.50 & 0.50 & 100.00 \\
\hline Greenery productive & 7.52 & 5.60 & 1.90 & 34.30 \\
\hline Rural buildings & 7.94 & 17.20 & -9.20 & -54.00 \\
\hline
\end{tabular}

\section{Results}

In the 1990s in Lake Głębokie Uścimowskie from 14 to 15 plant communities occurred, which occupied 2.9 ha of the lake. This represented only $14.1 \%$ of the lake (Table 2). In 2011 there were a slight growth in the number of phytocenoses (16), and a significant increase in the area of phytolittoral - 5.98 ha (Table $3)$. Especially there was a clear increase in the share of submerged communities. Their occurrence depends on conditions in water especially on the light conditions. In the 1990s they formed $3.8 \%$ of the phytolittoral, while in 2011 this increased up to $13.8 \%$.

The increase in phytolittoral surface of Lake Głębokie Uścimowskie and the range of occurrence of particular macrophyte groups were also reflected in the assessment of the ecological state of the lake. In the 1990s the range of ESMI index values, defined for stratified lakes, allowed the lake to be designated as one with poor ecological status, but already in 2011 
Table 2. The percentage share of each plant community creating the phytolittoral in Lake Głębokie Uścimowskie

\begin{tabular}{|l|r|r|r|}
\hline \multirow{2}{*}{ Plant community } & \multicolumn{3}{|c|}{ Lake Głębokie Uścimowskie } \\
\cline { 2 - 4 } & \multicolumn{1}{|c|}{1996} & \multicolumn{1}{c|}{1999} & \multicolumn{1}{c|}{2011} \\
\hline Acoretum calami & 7.9 & 17.5 & 4.5 \\
\hline Ceratophylletum demersi & 2.6 & - & 12.9 \\
\hline Eleocharitetum palustris & 5.3 & 5.0 & 0.3 \\
\hline Elodeetum canadensis & 7.9 & 10.0 & 6.4 \\
\hline Glycerietum maximae & 7.9 & 12.5 & 3.3 \\
\hline Hydrocharitetum morsus-ranae & 5.3 & 2.5 & 0.5 \\
\hline Myriophylletum spicati & 13.2 & 2.5 & 13.2 \\
\hline Nuphareto-Nymphaeetum albae & 2.6 & 2.5 & 12.2 \\
\hline Phragmitetum australis & 13.2 & 15.5 & 25.1 \\
\hline Potametum pectinati & 2.6 & 7.5 & 2.2 \\
\hline Potametum acutifolii & 15.8 & 5.0 & 0.2 \\
\hline Ranunculetum circinati & 5.3 & - & 1.5 \\
\hline Scirpetum lacustris & - & 2.5 & - \\
\hline Salicetum pentandro-cinerea & - & - & 0.7 \\
\hline Thelypteridi-Phragmitetum & 2.6 & 5.0 & 4.7 \\
\hline Typhetum angustifoliae & 2.6 & 2.5 & 4.3 \\
\hline Typhetum latifoliae & 5.3 & 10.0 & 8.0 \\
\hline
\end{tabular}

after a similar analysis of the lake it was placed in the upper limits of moderate ecological status of lakes (Table 3).

Table 3. Morphometric and phytolittoral characteristics of Lake Głębokie Uścimowskie and ESMI index values

\begin{tabular}{|c|c|c|c|c|}
\hline \multirow{2}{*}{ Parameter } & \multirow{2}{*}{ unit } & \multicolumn{3}{|c|}{ Lake Głębokie Uścimowskie } \\
\hline & & 1996 & 1999 & 2011 \\
\hline Lake surface & [ha] & \multicolumn{3}{|r|}{20.5} \\
\hline Maximum depth (found) & {$[\mathrm{m}]$} & \multicolumn{3}{|r|}{5.1} \\
\hline $\begin{array}{l}\text { Maximum depth of emergent } \\
\text { macrophytes' occurrence }\end{array}$ & {$[\mathrm{m}]$} & 1.0 & 1.0 & 1.3 \\
\hline $\begin{array}{l}\text { Maximum depth of submerged } \\
\text { macrophytes' occurrence }\end{array}$ & [m] & 1.5 & 1.5 & 3 \\
\hline \multirow{2}{*}{ Phytolittoral surface } & [ha] & 2.90 & 2.90 & 5.98 \\
\hline & [\%] & 14.10 & 14.10 & 29.17 \\
\hline \multirow{2}{*}{$\begin{array}{l}\text { Surface covered with } \\
\text { emergent macrophytes }\end{array}$} & [ha] & 2.00 & 2.10 & 3.14 \\
\hline & [\%] & 10.21 & 10.24 & 15.31 \\
\hline \multirow{2}{*}{\multicolumn{2}{|c|}{ ESMI }} & 0.15 & 0.15 & 0.33 \\
\hline & & poor & poor & moderate \\
\hline
\end{tabular}

The first sign of changes in the structure of macrophytes is their occurrence range. It is a consequence of the possibility of light penetration into the water. In the studied lake visibility increased causing macrophytes to colonize the lake up to $3 \mathrm{~m}$ depth. In the 1990s the scope of macrophytes' occurrence did not increase, despite a slight growth in visibility (Fig. 2).

An important component of the characterization of the ecological status of water reservoirs is submerged macrophytes. Their qualitative and quan-

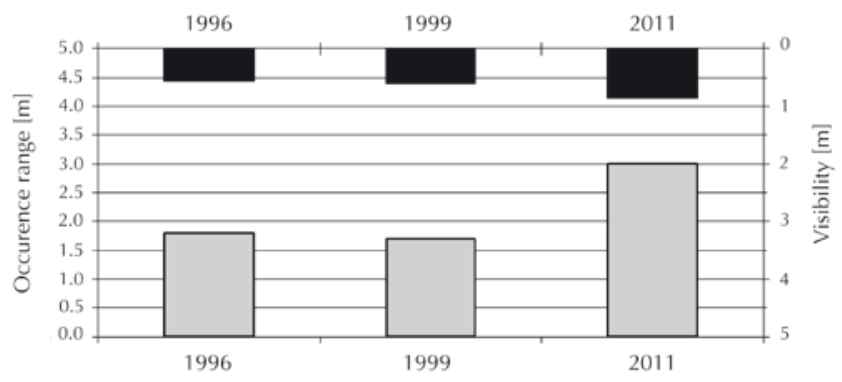

Fig. 2. Occurence range of macrophytes (grey bars) and Secchi disk depth (black bars) in Lake Głębokie Uścimowskie

titative structure depends on conditions prevailing in water (Stefan et al. 1997; Körner 2002 ).

In the 1990s there was almost no difference in the average values of submerged macrophyte biomass, while a significant increase in biomass of macrophytes occurred in this group in 2011 (Fig. 3).

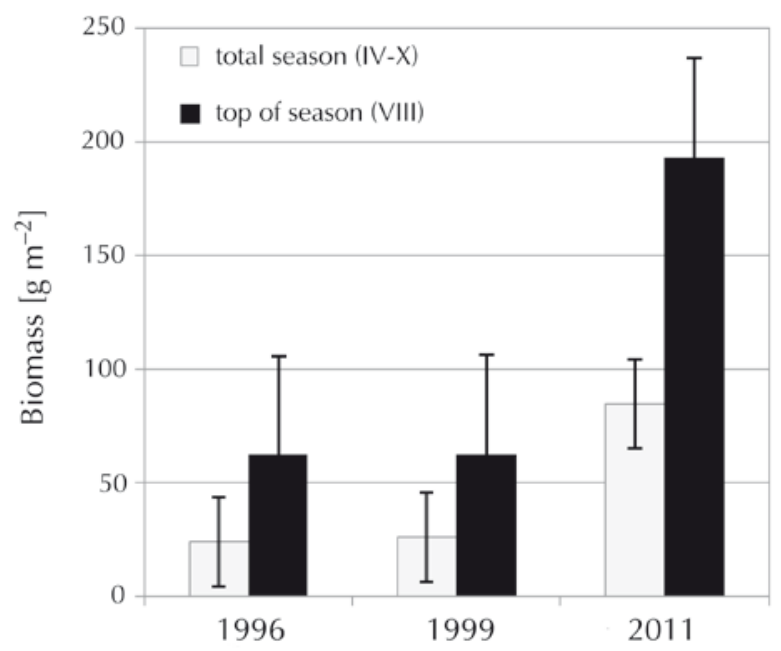

Fig. 3. Average biomass of submerged macrophytes in Lake Głębokie Uścimowskie

The submerged vegetation of Lake Głębokie Uścimowskie was dominated by nutrient tolerant species, with Ceratophyllum demersum and Myriophyllum spicatum (Fig. 4). Participation in the biomass of individual species changed in the following years of the study.

Potamogeton acutifolii clearly dominated in biomass in the 1990s, while in 2011 the share of most species was well balanced (Fig. 4). There was no effect of dominance. A favourable trend was the abundant occurrence of evergreen Chara species. 


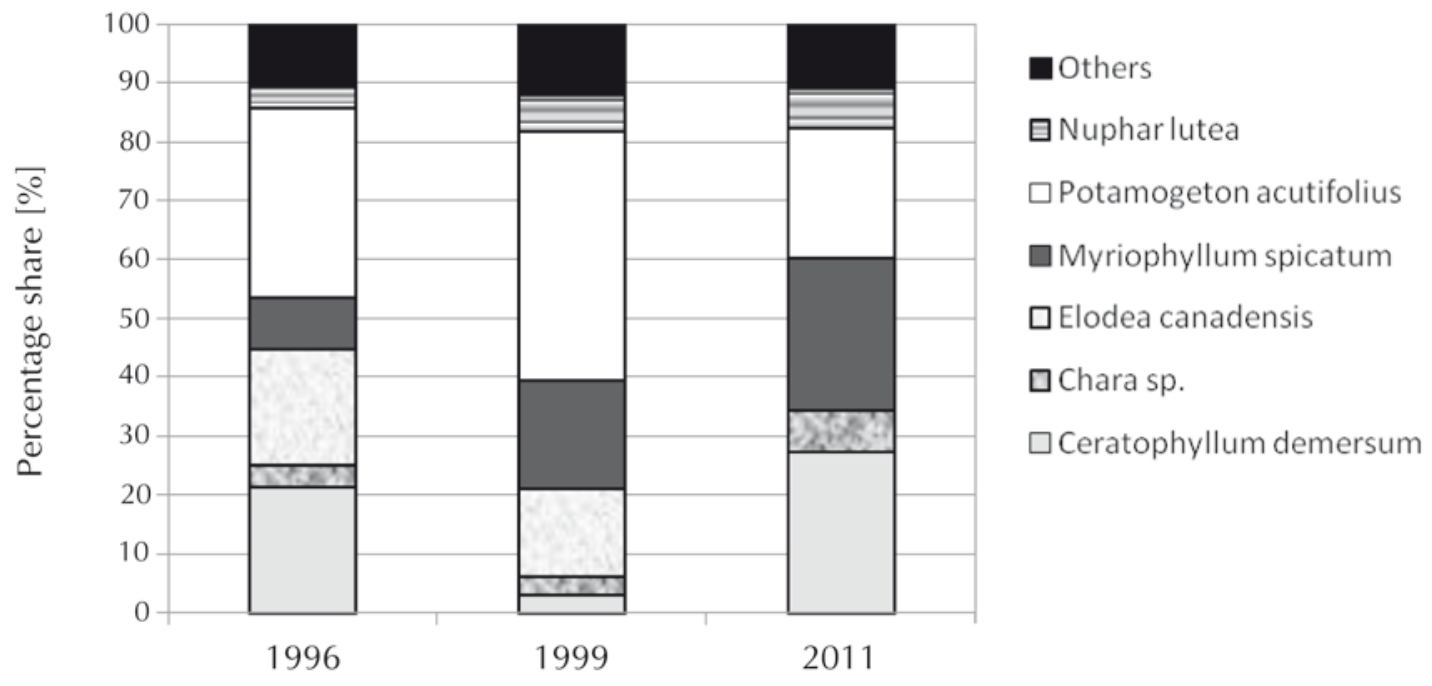

Fig. 4. Percentage share of particular species of submerged macrophytes in biomass

In 1999, the lowest average values of submerged macrophyte biomass were in the transect with village buildings, where in spring they did not exist at all. The highest value was reached during the summer season in the transect located in the vicinity of the forest. In
2011, a similar trend was observed; however, in the urban transect macrophytes occurred throughout the growing season, also reaching much higher values (Fig. 5). All increases in biomass were statistically significant $(\mathrm{r}=0.9, \mathrm{p}<0.05)$.

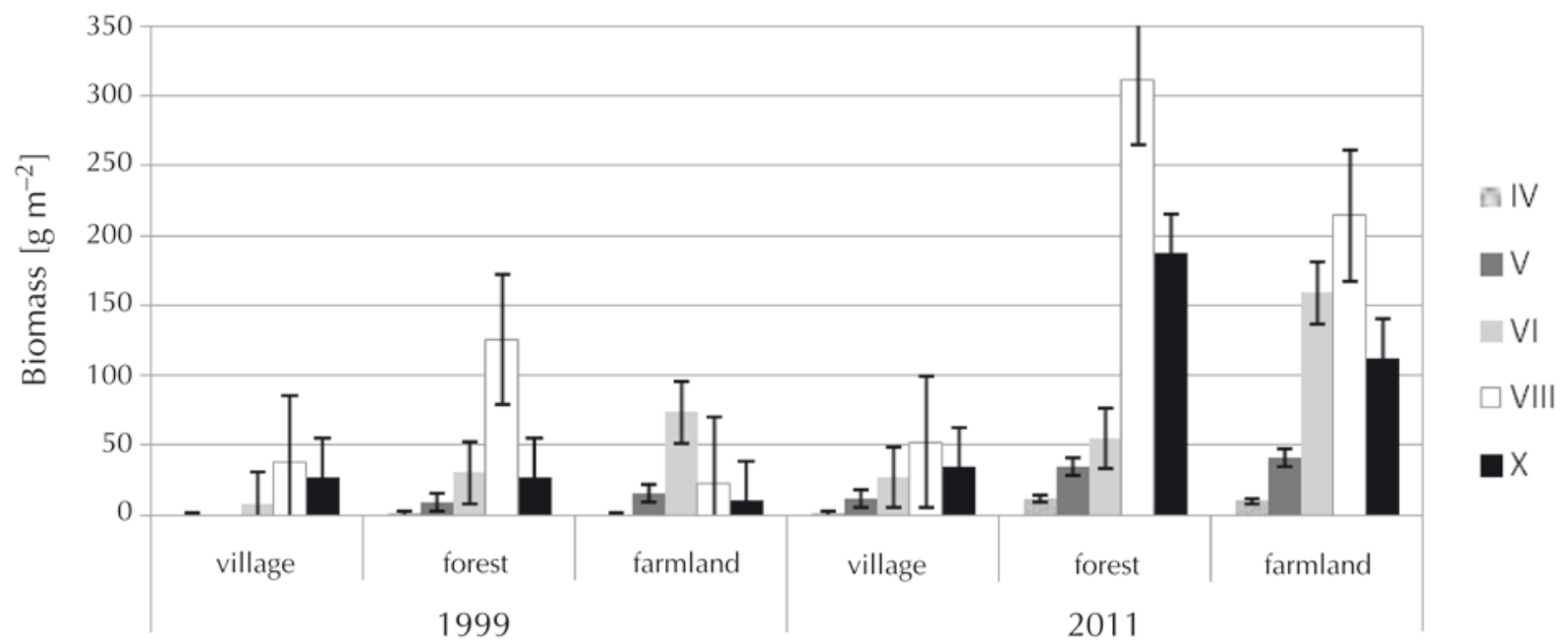

Fig. 5. Average biomass of submerged macrophytes in a growing season in 1999 and 2011

In 1999, the maximum range of macrophytes' occurrence was only $1.8 \mathrm{~m}$, while the highest biomass value reached up to $1.5 \mathrm{~m}$ depth. In 2011, macrophytes occurred even at $3 \mathrm{~m}$ depth, clearly reaching the highest values of biomass in the forest transect. A slightly lower biomass of macrophytes was reached in the transect adjacent to agricultural fields (Fig. 6).
Physico-chemical parameters analysed in relation to the 1990s showed negligible changes, which were not so significant and in the overall evaluation did not change the trophic status. Despite a significant rise in the assessment of the ecological status of Lake Głębokie Uścimowskie, trophy index values determined using Carlson's index qualify them as eutrophic lakes, but with a clear decreasing trend (Table 4). 


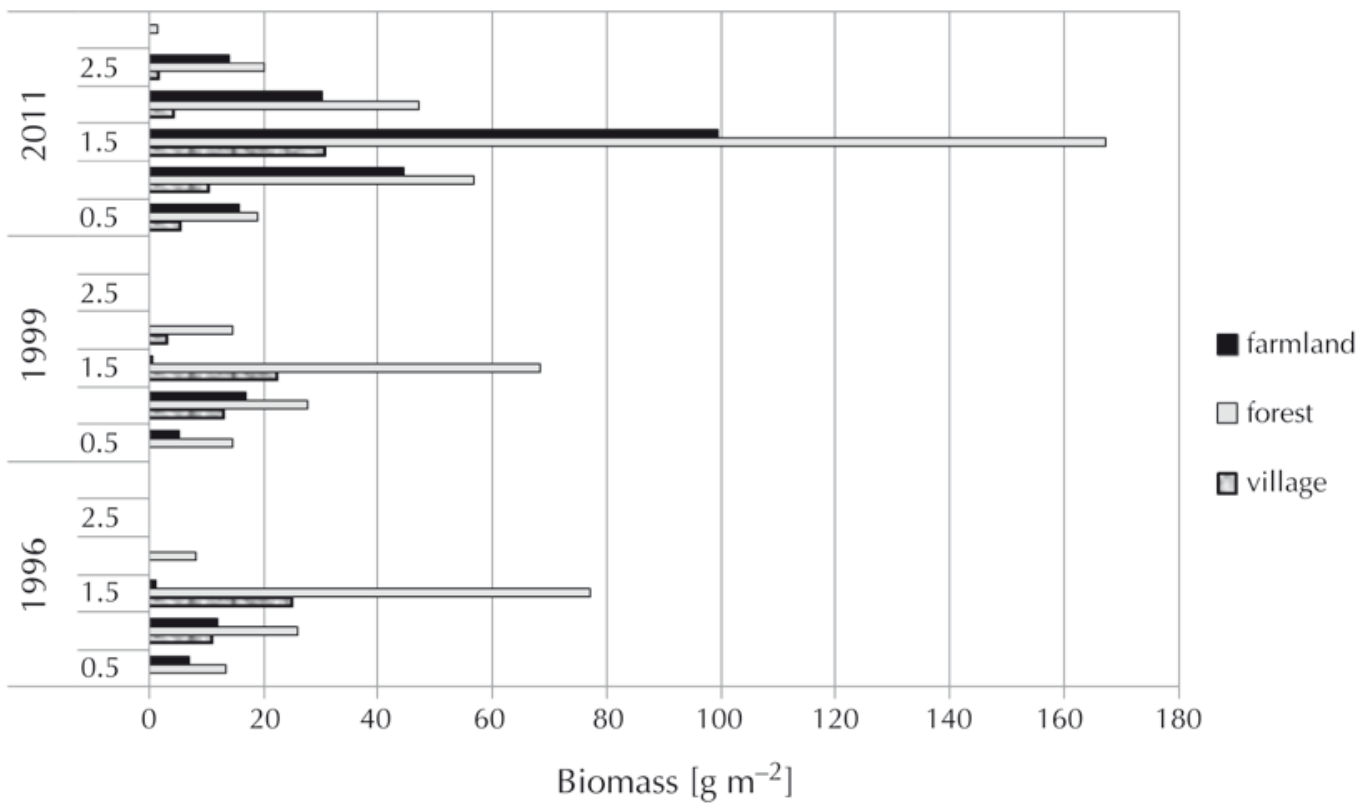

Fig. 6. Average biomass of submerged macrophytes at particular depths

Table 4. Selected physico-chemical parameters of water quality in Lake Głębokie Uścimowskie

\begin{tabular}{|c|c|c|}
\hline Parameter & 1999 & 2011 \\
\hline Secchi disc depth (visibility) [m] & 0.55 & 0.86 \\
\hline Temperature $\left[{ }^{\circ} \mathrm{C}\right]$ & 20.35 & 21.1 \\
\hline Oxygen concentration in water $\left[\mathrm{mg} \mathrm{O}_{2} \mathrm{dm}^{-1}\right]$ & 12.13 & 6.2 \\
\hline Electrolytic conductivity $\left[\mu \mathrm{S} \mathrm{cm}^{-1}\right]$ & 204.33 & 202.1 \\
\hline $\mathrm{pH}$ & 7.98 & 8.28 \\
\hline Oxygen saturation [\%] & 135 & 71.3 \\
\hline $\mathrm{N}^{-\mathrm{NH}_{4}}{ }^{+}\left[\mathrm{mg} \mathrm{N} \mathrm{dm}^{-1}\right]$ & 0.32 & 0.648 \\
\hline $\mathrm{N}-\mathrm{NO}_{3}^{-}\left[\mathrm{mg} \mathrm{N} \mathrm{dm}^{-1}\right]$ & 0.70 & 0.57 \\
\hline $\mathrm{P}_{-} \mathrm{PO}_{4}{ }^{3-}\left[\mathrm{mg} \mathrm{PO}_{4} \mathrm{dm}^{-1}\right]$ & 0.04 & 0.01 \\
\hline Total phosphorus [mg PO $\mathrm{dm}^{-1}$ ] & 0.38 & 0.26 \\
\hline $\mathrm{Ca}^{2+}\left[\mathrm{mg} \mathrm{Ca} \mathrm{dm}^{-1}\right]$ & 18.2 & 18.9 \\
\hline $\mathrm{Na}^{+}\left[\mathrm{mg} \mathrm{Na} \mathrm{dm}^{-1}\right]$ & 10.27 & 5.0 \\
\hline $\mathrm{K}^{+}\left[\mathrm{mg} \mathrm{K} \mathrm{dm}^{-1}\right]$ & 10.93 & 5.2 \\
\hline $\mathrm{TSI}(\mathrm{SD})$ & 71.50 & 62.17 \\
\hline TSI(TN) & - & 45.01 \\
\hline TSI(TP) & 45.85 & 51.16 \\
\hline Average TSI = [(TSI(SD)+ TSI(TN)+ TSI(TP))/3] & 58.68 & 52.78 \\
\hline
\end{tabular}

In the 1990s the average values of biomass for the period of maximum development of macrophytes were $0.03 \mathrm{t}$ per ha of the lake and were typical for highly eutrophic lakes (Table 5). By contrast, the value of $0.3 \mathrm{t}$ per ha of the lake, which in the studied lake submerged macrophytes reached in 2011, is typical for eutrophic lakes (Pieczyńska and Ozimek 1976; Królikowska 1997; Sender 2010). Differences in biomass between years of research were statistically significant (test $\mathrm{T}=0.047, \mathrm{p}>0.05$ ). Biomass values determined for the entire growing season and for a month in which the macrophytes reached the highest values of biomass were not statistically significant (test $\mathrm{T}=0.15$, $\mathrm{p}>0.05)$.

Table 5. Total biomass (dry mass) of submerged macrophytes in Lake Głębokie Uścimowskie

\begin{tabular}{|l|c|c|c|c|}
\hline \multirow{2}{*}{ Year } & \multicolumn{2}{|c|}{ Entire growing season } & \multicolumn{2}{c|}{ Peak of growing season } \\
\cline { 2 - 5 } & T ha $^{-1}$ lake surf. & T ha $^{-1}$ phytolittoral surf. & T ha $^{-1}$ lake surf. & T ha $^{-1}$ phytolittoral surf. $^{2}$ \\
\hline 1996 & 0.009 & 0.078 & 0.028 & 0.290 \\
\hline 1999 & 0.010 & 0.080 & 0.030 & 0.300 \\
\hline 2011 & 0.110 & 0.400 & 0.200 & 0.920 \\
\hline
\end{tabular}




\section{Discussion}

Both the occurrence range and increase in Secchi disk visibility in the studied Lake Głębokie Uścimowskie can provide a clear stimulus which has affected their colonization. In the lake there was a significant increase in the area covered by macrophytes, thereby significantly increasing their biomass. The ecological status of Lake Głębokie Uścimowskie, determined on the basis of the macrophyte index (ESMI), as well as a slight decline in index trophy, were also affected owing to the sewerage system of Głębokie village. It was built and put into use in 2006. Six years after its launch, lake water is largely improved, which resulted among other things in an increased area of phytolittoral, a significant increase in biomass and distribution of submerged macrophytes. Sewage management can significantly improve the ecological status of lakes, which influences the resuccession of macrophytes also in the investigated lake (Wróbel and Królikowska 1999). Fulfilment of conditions for sustainable development of agriculture requires complex water management to be carried out within the catchment area. Water resources are formed primarily in agricultural and forest areas; here they are subject to retention and are partially used up (Mioduszewski 1999). Proper water management in the agricultural landscape determines the quality and quantity of water; it is also the basis for forming ecological balance. The basis is sustainable ecological development of rural areas.

The changes that occurred in the catchment area of the investigated lake are also an important factor, which has affected the shaping of the phytocenotic structure of the studied lake. A clear increase in forest areas in particular may cause reduction in nutrient runoff (Kufel 1999; Górniak 1999). Another reason for the modification of the structure of plants is transformation from agriculture to grasslands and peatlands, which in this case play a buffer role (Hilbricht-Ilkowska 1995).

\section{References}

Bernatowicz S., 1959, Zmienność flory naczyniowej w jeziorze Arklickim (Variability of vascular flora in Lake Arklickie), Pol. Arch. Hydrobiol. 5(2): 121-130 (in Polish).

Carlson R.E., 1977, A trophic state index for lakes, Limnol. Oceanogr. 22(2): 361-369.

Ciecierska H., 2004, Ecological state of reference lakes of the European Intercalibration Network, located in the Masurian Landscape Park (NE Poland), Limnol. Rev. 4: 45-50.

Ciecierska H., 2008, Makrofity jako wskaźniki stanu ekologicznego jezior (Macrophytes as indicators of ecological state of lakes), Rozpr. Monogr. 139, Wyd. UWM, Olsztyn, p. 202 (in Polish).

Fijałkowski D., 1959, Szata roślinna jezior ŁęczyńskoWłodawskich i przylegających do nich torfowisk (Plant vegetation in lakes and adjacent peat bogs of ŁęcznaWłodawa Lakeland), Ann. UMCS B 14(3): 131-206 (in Polish, English summary).

Fukarek F., 1967, Fitosocjologia (Phytosociology), PWRiL, Warszawa, p. 217 (in Polish).

Górniak A., 1999, Rola hydrologii i charakteru zlewni w kształtowaniu chemizmu wód jezior (The role of hydrology and type of catchment area in shaping of lakes' water chemistry), [in:] Górniak A. (ed.), Mat. Ogólnopol. Konf. Naukowej "Współczesne kierunki badań hydrobiologicznych”, Supraśl 22-24 września 1999, Wyd. UwB, Białystok: 61-68 (in Polish).

Hillbricht-Ilkowska A., 1995, Managing ecotones for nutrient and water, Ecol. Int. 22: 73-93.

Hillbricht-Ilkowska A., Kostrzewska-Szlakowska I., 1996, Ocena ładunku fosforu i stanu zagrożenia jezior rzeki Krutyni (Pojezierze Mazurskie) oraz zależności pomiędzy ładunkiem a stężeniem fosforu w jeziorach (Phosphorus load rating and level of risk of lakes of the River Krutynia (Masurian Lakeland) and the relationship between the load and the concentration of phosphorus in lakes), Zesz. Nauk. Kom. Nauk "Człowiek i Środowisko" PAN 13: $97-$ 123 (in Polish, English summary).

Kłosowski S., Tomaszewicz H., 1996, Zbiorowiska roślinności brzegowej systemu rzeczno-jeziornego rzeki Krutyni (Vegetation communities of the shoreline of the riverlake system of the River Krutynia), Zesz. Nauk. Kom. Nauk "Człowiek i Środowisko" PAN 13: 345-376 (in Polish, English summary).

Körner S., 2002, Loss of submerged macrophytes in shallow lakes in North-Eastern Germany, Internat. Rev. Hydrobiol. 87(4): 375-384.

Kufel L., 1999, Transport pierwiastków biogennych w zlewniach Mazurskiego Parku Krajobrazowego (Transport of biogenic elements in the catchment areas of the Masurian Landscape Park), [in:] Zdanowski B., Kamiński M., Martyniak A. (eds), Funkcjonowanie i ochrona ekosystemów wodnych na obszarach chronionych (Functioning and protection of water ecosystems in protected areas), Wyd. IRS, Olsztyn: 153-165 (in Polish). 
Królikowska J., 1997, Eutrophication processes in a shallow, macrophyte-dominated lake - species differentiation, biomass and the distribution of submerged macrophytes in Lake Łuknajno (Poland), Hydrobiologia 342/343: 411-416.

Lampert W., Sommer U., 1996, Ekologia wód śródlądowych (Freshwater ecology), Wyd. Nauk. PWN, Warszawa, p. 390 (in Polish).

Matuszkiewicz W., 2008, Przewodnik do oznaczania zbiorowisk roślinnych Polski (Guidebook for the determining of plant associations in Poland), Wyd. Nauk. PWN, Warszawa, p. 536 (in Polish).

Mioduszewski W., 1999, Ochrona i kształtowanie zasobów wodnych w krajobrazie rolniczym (The protection and development of water resources in the agricultural landscape), Wyd. IMUZ, Falenty, p. 165 (in Polish).

Pieczyńska E., Ozimek T., 1976, Ecological significance of lake macrophytes, Int. Ecol. Environ. 2: 115-128.

Radwan S., Chmielewski T.J., Ozimek T., 1998, Struktura i funkcjonowanie ekotonów woda/ląd w różnych typach troficznych jezior Polesia Lubelskiego (Structure and functioning of water/land ecotones in different trophic type of lakes in the Polesie Lubelskie), [in:] Radwan S. (ed.) Ekotony słodkowodne. Struktura - Rodzaje Funkcjonowanie (Freshwater ecotones. Structure - types - functioning), Wyd. UMCS, Lublin, 17-31 (in Polish, English summary).

Radwan S., Kornijów R., Kowalik W., Jarzynowa B., Zwolski W., Kowalczyk C., Popiołek B., 1987, Ecological and fishery characteristic of lake situated in the future Western Polesie National Park. Ann. UMCS C 42(14): 163-184.
Sender J., 2004, Struktura jakościowa i ilościowa zbiorowisk makrofitów w wybranych jeziorach Pojezierza Łęczyńsko-Włodawskiego (Qualitative and quantitative structure of plant communities in some lakes in ŁęczyńskoWłodawskie Lakeland) [dissertation], UAM Poznań, p. 190 (in Polish).

Sender J., 2009, Changes in structure of macrophyte communities in the chosen lakes of Łęczna-Włodawa Lake District, Ecohydrol. Hydrobiol. 9(2-4): 237-245.

Sender J., 2010, Przekształcenia struktury hydrobotanicznej pod wpływem czynników naturalnych i antropogenicznych wybranych płytkich jezior na Pojezierzu Łęczyńsko-Włodawskim. (Changes in hydrobotanical structure under natural and anthropogenic factors in selected shallow lakes in Łęczyńsko-Włodawa Lakeland), [in:] Nędzarek A., Kubiak J., Tórz A. (eds), Anthropogenic and natural transformation of lakes. Vol. 4, Wyd. PTLim, Szczecin:111-117 (in Polish).

Stefan E.B., Weisner-John A., Strand-Hakan S., 1997, Mechanisms regulating abundance of submerged vegetation in shallow eutrophic lakes, Oecologia 109: 592-599.

Wróbel J., Królikowska J., 1999, Stan roślinności wodnej płytkiego, eutroficznego jeziora Oświn w pięć lat po spiętrzeniu (State of aquatic macrophytes of the shallow and eutrophic Lake Oświn, 5 years after damming), [in:] Radwan S., Kornijów R. (eds), Problemy aktywnej ochrony ekosystemów wodnych i torfowisk w Polskich Parkach Narodowych (Problems of the active protection of aquatic ecosystems and peat bogs in Polish national parks), Wyd. UMCS, Lublin: 239-244 (in Polish). 